\title{
Selection of circulating PD-1+ lymphocytes from cancer patients enriches for tumor-reactive and mutation-specific lymphocytes
}

\author{
Alena Gros ${ }^{1 *}$, Eric Tran², Maria R Parkhurst ${ }^{1}$, Pasetto Anna ${ }^{2}$, Sadia llyas ${ }^{2}$, Todd D Prickett ${ }^{1}$, Jared J Gartner ${ }^{2}$, \\ Paul F Robbins², Jessica S Crystal ${ }^{2}$, Kasia Trebska-Mcgowan', John R Wudnerlich², James C Yang ${ }^{3}$, \\ Steven A Rosenberg ${ }^{2}$
}

From 30th Annual Meeting and Associated Programs of the Society for Immunotherapy of Cancer (SITC 2015)

National Harbor, MD, USA. 4-8 November 2015

\section{Background}

$\mathrm{T}$ cells targeting unique somatic mutations appear to play an important role in the antitumor responses observed following $\mathrm{T}$ cell transfer, and isolation of mutation-specific lymphocytes and $\mathrm{T}$-cell receptors has become a major obstacle to the development of more effective immunotherapies. The detection of tumor-reactive and mutation-specific cells in patients with cancer has been largely restricted to tumor-infiltrating lymphocytes, but mutationspecific cells are thought to be far less prevalent in peripheral blood, a more accessible and abundant source of $\mathrm{T}$ cells. We recently reported that expression of PD-1 identifies the patient-specific repertoire of tumor-reactive cells infiltrating melanoma tumors. Given these findings, we explored the utility of PD-1 expression on peripheral blood lymphocytes to detect and enrich for tumor and neoantigen specific lymphocytes.

\section{Methods}

To this end, peripheral blood CD8+ lymphocytes were separated based on the expression of PD-1 into CD8+PD-1- and CD8+PD-1+ and CD8+PD-1hi cells, and expanded in vitro for 15 days. Circulating $\mathrm{T}$ cell subsets were subsequently screened for recognition of mutated antigens identified by whole exome sequencing using a high throughput and personalized approach that enables the expression of all the potential tumor neoantigens in the autologous antigen-presenting cells. In addition, recognition of shared melanoma differentiation antigens and cancer germline antigens was also evaluated.

\section{Results}

PD-1+ lymphocytes represented a small percentage of all the circulating CD8+ cells in patients with metastatic melanoma. We found that selection of CD8+PD-1+ lymphocytes circulating in peripheral blood, but not the CD8+ or CD8+PD-1- cells, led to direct enrichment of tumor-reactive cells from peripheral blood in all four patients studied. In three out of four melanoma patients, the peripheral blood CD8+PD-1+ and PD-1hi cells contained mutation-specific lymphocytes targeting 3, 3 and 1 unique patient-specific neoantigens, respectively. In addition, circulating CD8+PD- $1+$ and PD-1hi lymphocytes from all four patients evaluated were also enriched in $\mathrm{T}$ cells targeting at least one cancer germline antigen, including NY-ESO-I, MAGE-A3, and SSX2. Neither mutation-specific nor cancer germline-specific lymphocytes were detected in the peripheral blood CD8+ or the CD8+PD-1- populations.

\section{Conclusion}

Our findings provide evidence that peripheral blood CD8+PD-1+ from cancer patients are enriched in naturally-occurring tumor-reactive and mutation-specific cells and provide a novel strategy to develop personalized $\mathrm{T}$ cell based therapies to treat cancer. 


\section{Authors' details}

'National Cancer Institute, National Institutes of Health, Bethesda, MD, USA

${ }^{2}$ Surgery Branch, National Cancer Institute, National Institutes of Health,

Bethesda, MD, USA. ${ }^{3}$ National Institutes of Health, Bethesda, MD, USA.

Published: 4 November 2015

doi:10.1186/2051-1426-3-S2-02

Cite this article as: Gros et al: Selection of circulating PD-1+

lymphocytes from cancer patients enriches for tumor-reactive and

mutation-specific lymphocytes. Journal for ImmunoTherapy of Cancer 2015

3(Suppl 2):O2.

Submit your next manuscript to BioMed Central and take full advantage of:

- Convenient online submission

- Thorough peer review

- No space constraints or color figure charges

- Immediate publication on acceptance

- Inclusion in PubMed, CAS, Scopus and Google Scholar

- Research which is freely available for redistribution

Submit your manuscript at 